\title{
Effects of inclusion of purple prairie clover (Dalea purpurea Vent.) with native cool- season grasses on in vitro fermentation and in situ digestibility of mixed forages
}

Kai Peng ${ }^{1,2} \mathbb{B}$, Gemma L. Gresham ${ }^{3}$, Tim A. McAllister $^{2}$, Zhongjun Xu², Alan Iwaasa ${ }^{4}$, Mike Schellenberg ${ }^{4}$, Alex V. Chaves ${ }^{3}$ and Yuxi Wang ${ }^{2^{*}}$

\begin{abstract}
Background: Incorporation of legume species into native North American pastures is considered an effective method to increase native pasture productivity and improve the nutritive value of forage. This study evaluated the effects of inclusion of purple prairie clover (PPC, Dalea purpurea Vent.), a native legume forage, with native coolseason grasses on the in vitro fermentation and in situ digestibility of mixed forages.

Methods: Whole plant PPC and mixtures of cool-season grasses were harvested when the PPC reached the vegetative (VEG), full flower (FL) and seedpod (SP) stages, and were combined in ratios (DM basis) of 0:100, 25:75, 50:50, 75:25 and 100:0 at each maturity. In vitro ruminal incubations using these mixtures were conducted for $48 \mathrm{~h}$ to determine gas production (GP), in vitro DM disappearance (IVDMD), total volatile fatty acids (VFA) and ammonia-N production. Mixtures of forages harvested when the PPC reached the FL stage and 50:50 mixture of forages harvested at VEG, FL and SP stages were incubated in the rumen of three heifers for $0,2,6,12,24,48,72$ and $96 \mathrm{~h}$ to determine in situ degradabilities of DM, neutral detergent fibre (aNDF) and crude protein (CP).

\footnotetext{
* Correspondence: yuxi.wang@canada.ca

${ }^{2}$ Agriculture and Agri-Food Canada, Lethbridge Research and Development

Centre, Lethbridge, AB T1J 4B1, Canada

Full list of author information is available at the end of the article
}

(c) The Author(s). 2020 Open Access This article is distributed under the terms of the Creative Commons Attribution 4.0 International License (http://creativecommons.org/licenses/by/4.0/), which permits unrestricted use, distribution, and reproduction in any medium, provided you give appropriate credit to the original author(s) and the source, provide a link to the Creative Commons license, and indicate if changes were made. The Creative Commons Public Domain Dedication waiver (http://creativecommons.org/publicdomain/zero/1.0/) applies to the data made available in this article, unless otherwise stated. 
(Continued from previous page)

Results: Contents of aNDF and ADF increased $(P<0.01)$, while CP decreased $(P<0.001)$ as PPC matured. Concentrations of extractable condensed tannins in PPC ranked as FL $>$ VEG $>S P(P<0.05)$. Regardless of PPC proportions in the mixture, GP decreased $(P<0.05)$ with increasing PPC maturity. Increasing PPC proportions linearly increased $(P<0.001)$ GP, IVDMD and total VFA at VEG, but linearly decreased $(P<0.001)$ them at SP. Irrespective of PPC maturity, ammonia-N production linearly increased $(P<0.01)$ with increasing proportions of PPC and the concentration was higher $(P<0.05)$ at VEG than at FL and SP stages. Increasing proportion of PPC at either maturity linearly increased $(P<0.001)$ molar percentage of acetate $(A)$ and branched-chain VFA, but linearly decreased $(P<0.001)$ molar percentage of propionate $(P)$, resulting in a linearly increase $(P<0.001)$ in the A:P ratio. Increasing FL PPC in the mixture linearly and quadratically $(P<0.01)$ increased $a$ (soluble fraction), but linearly and quadratically decreased $(P<0.01) b$ (potentially degradable fraction) for DM and aNDF, resulting in linear $(P<0.05)$ and quadratic $(P<0.01)$ increases in DM and aNDF maximum potential degradabilities $(a+b)$. Effective degradabilities of DM and aNDF were also linearly and quadratically increased $(P<0.05)$, and CP was quadratically increased $(P<0.05)$ with increasing FL PPC, with the greatest effective degradability being observed with ratios between 50:50 and 75:25. Ruminal maximum potential degradabilities of DM and aNDF decreased $(P<0.001)$ as the forage matured. Effective degradability of DM ranked as VEG $>$ FL $>S P(P<0.001)$, whereas the effective degradability of aNDF was similar between VEG and FL and both were greater $(P<0.01)$ than SP.

Conclusions: Inclusion of vegetative PPC in a mixed forage diet resulted in the greatest digestibility and incorporation of PPC before seedpod stage with native grasses had a positive effect on ruminal fermentation. Effects of PPC on ruminal digestion depend on both the stage of maturity and its proportion in mixed legume-grass pastures. Pastures containing 50\% of PPC in full flower stage would likely provide the greatest quality diet to grazing ruminants subject to potential animal selectivity.

Keywords: Condensed tannins, Cool-season grass, In vitro fermentation, In situ digestibility, Purple prairie clover

\section{Background}

Grasses in native pasture are usually the principal forage source in the prairie region of North America during late season grazing. However, nutritive value of grasses rapidly declines in the latter half of the grazing season [1]. Inclusion of native legume species in rehabilitated native prairie pasture in North America is considered an effective method to increase pasture productivity and quality while increasing the protein concentration of the forage [2, 3]. Rehabilitation of native pasture is the process of re-establishing the structure, function, and integrity of native ecosystems and their habitats. The agronomic and nutritional advantages of inclusion of legumes in grass-based pasture systems have been well documented [4-7]. These include increased pasture productivity, herbage nutritive value and resource efficiency through the symbiotic nitrogen fixation and thereby improve animal performance. As a result, this practice can extend the grazing season and reduce the cost of beef production on native pasture.

Purple prairie clover (PPC, Dalea purpurea Vent.) is a perennial native legume that is well adapted to the North American prairies and has higher palatability and digestibility than other native legumes such as false indigo (Amorpha fruticosa L.), blue wild indigo (Baptisia australis (L.) R. Br.) and wild senna (Senna hebecarpa (Fernald) Irwin \& Barneby) [8]. The PPC generally blooms July through September and has the ability to extend and improve the sward forage quality during the entire grazing season. These properties could enable PPC to be the most desirable native legume for the remediation of prairie native grass pastures [9]. In addition, PPC contains high concentration of condensed tannins (CT) that possess antimicrobial, antiparasital, antioxidant, anti-bloat properties and modulate the immune system of animals [10]. Our previous studies showed that PPC CT up to $82 \mathrm{~g} / \mathrm{kg}$ DM had varying impact on ruminal feed digestion and animal growth performance depending on the conservation method of PPC and its proportion in the diet [11-13]. Therefore, defining the optimal levels of PPC in consumed mixed forages is needed to target the most desirable density of PPC in mixed native grass pastures. Although the in vitro ruminal digestion of PPC and PPC-grass mixtures have been evaluated [3,11], little information is available on the impact of PPC on ruminal digestion of PPC-grass mixtures at varying ratios and stages of maturity. This information is needed to estimate the optimal density of PPC in rehabilitated native pasture.

The objective of this study was to assess the impact of mixing different levels of PPC at varying stages of maturity with native cool-season grasses on the in vitro ruminal fermentation and in situ nutrient degradation.

\section{Materials and methods}

\section{Forage preparation}

Whole plant PPC (AC Lamour) and a mixture of coolseason grasses including western wheatgrass (Pascopyrum smithii (Rydb.), WR Poole), northern wheatgrass (Agropyron cristatum, Critana), green wheatgrass (Elymus hoffmannii Jensen \& Asay, AC Mallard), little bluestem (Schizachyrium 
scoparium, Badlands), blue grama (Bouteloua gracilis, Bad River), awned wheatgrass (Agropyron cristatum, AC Pintail), Canada wildrye (Elymus canadensis L., Mandan), needleand-thread grass (Hesperostipa comate, AC Sharptail) were collected from three rehabilitated native pastures that were seeded in 2011. Fertilizer (11-51-00) was used as a seed carrier during seeding to prevent seed bridging. The ratio of seed mix to fertilizer was 1:1 and was seeded at a rate of approximately $9 \mathrm{~kg} / \mathrm{ha}$. The PPC seed was $2 \%$ of the seed mixture. The pastures were located at the Swift Current Research and Development Centre (SK, Canada; latitude $\mathrm{N} 50^{\circ} 17^{\prime}$, longitude $\mathrm{W} 107^{\circ} 41^{\prime}$, 825 elevation) on a Swinton Loam soil (Orthic Brown Chernozem) [11]. Samples of both grasses and PPC were collected with a pair of scissors about $2.0 \mathrm{~cm}$ above ground level from three locations in each pasture when the PPC reached the vegetative (VEG; June in 2015), full flower (FL; July in 2015) and seedpod (SP; August in 2015) stages of maturity of PPC. Upon collection, PPC was manually separated from mixed grasses and each was composited by pasture and maturity and freeze-dried [12]. Dried samples were ground through a 1.0-mm screen, with PPC and the grass mixture from each pasture at each maturity were combined in ratios (PPC: grasses) of 0:100, 25: 75, 50:50, 75:25 and 100:0.

\section{Determination of in vitro ruminal fermentation of forage mixture}

Approximately $0.5 \mathrm{~g}$ DM of each forage mixture was weighed into acetone-washed, pre-weighted F57 filter bags (pore size of $25 \mu \mathrm{m}$; ANKOM Technology Corp.) [12]. Bags were sealed and placed in $125-\mathrm{mL}$ serum vials in preparation for in vitro ruminal batch culture fermentation.

Inoculum was prepared on the day of the incubation using fresh rumen fluid that was collected $2 \mathrm{~h}$ after the morning feeding and combined in equal volumes from three ruminally cannulated Angus heifers $(480 \pm 5.5 \mathrm{~kg}, 32$ months). The heifers were fed (DM basis) a forage diet containing $50 \%$ alfalfa hay, $35 \%$ barley silage, $12 \%$ dry-rolled barley and $3 \%$ of a vitamin and mineral supplement as per the National Research Council [14] recommendations. All heifers were fed at 08:00 $\mathrm{h}$ and provided ad libitum access to feed and water and were cared for in accordance with standards of Canadian Council on Animal Care [15]. Rumen fluid collected from five locations within the rumen was strained through 4 layers of cheesecloth and immediately transported in an anaerobic and pre-warmed container to the laboratory. Rumen fluid was then combined $(1: 3, v / v)$ with pre-warmed mineral buffer $\left(39^{\circ} \mathrm{C}\right)$ [16] to generate the inoculum.

Vials containing substrate were warmed to $39^{\circ} \mathrm{C}$ and flushed with $\mathrm{O}_{2}$-free $\mathrm{CO}_{2}$ prior to the addition of $60 \mathrm{~mL}$ of inoculum. Vials were immediately sealed and affixed to a rotary shaker platform $(160 \mathrm{r} / \mathrm{min})$ housed in a $39^{\circ} \mathrm{C}$ incubator (Forma Scientific reach-in incubator, Model \#
39419-1, 120 V, 60 Hz). Triplicate vials containing inoculum without substrate were also incubated to serve as blank controls. Vials for $0 \mathrm{~h}$ incubation were placed on ice immediately following addition of inoculum.

Headspace gas production (GP) was measured in the vials at $3,6,9,12,24$ and $48 \mathrm{~h}$ post-inoculation by inserting a 23 -gauge $(0.6 \mathrm{~mm})$ needle attached to a pressure transducer (model 15078-193; Fisher Scientific, Pittsburgh, PA, USA) connected to a visual display device (Data Track, Christchurch, UK). The recorded cumulative gas pressure, corrected for the gas released from the blanks, was converted to volumes $(\mathrm{mL})$ using the equation of Mauricio et al. [17]:

$\mathrm{GP}=0.18+3.697 \mathrm{P}_{\mathrm{t}}+0.0824 \mathrm{P}_{\mathrm{t}}^{2}$ where $\mathrm{GP}$ is gas production, $\mathrm{mL} ; \mathrm{P}_{\mathrm{t}}$ is pressure transducer reading value, $\mathrm{psi}$.

Fermentation vials were removed from the incubator after $48 \mathrm{~h}$ of incubation and placed in ice-water. The bags were removed from vials, manually washed under running tap water until the stream was clear and dried in an oven at $55^{\circ} \mathrm{C}$ for $48 \mathrm{~h}$. Bags were used to estimate in vitro dry matter disappearance (IVDMD) by subtracting the loss of DM from the bags from the initial DM incubated. The liquid fraction was processed immediately for determinations of ammonia- $\mathrm{N}$ and volatile fatty acids (VFA) as described by Wang et al. [16]. Two runs of each incubation with six replicates for each treatment per run were conducted.

\section{Determination of ruminal degradability of the forage mixtures}

Whole plant PPC and grasses harvested at FL of PPC as described above were combined in ratios of 0:100, 25:75, 50:50, 75:25 and 100:0 (PPC: grasses) to evaluate the effect of PPC on ruminal degradability of the forage mixtures. In addition, PPC and grasses harvested at each maturity of PPC (VEG, FL and SP) were combined at a ratio (DM basis) of 50:50 to determine the effect of maturity on the degradability of the mixture. For these determinations, freeze-dried PPC and grasses were ground to pass through a $4.0 \mathrm{~mm}$ screen before mixing and the same three heifers used as rumen fluid donors for the in vitro incubation were used in the in situ experiment.

The procedure for incubation of the nylon bags and subsequent determinations of DM, neutral detergent fibre (aNDF) and CP disappearances were the same as described by Huang et al. [12]. Mixed forage samples were weighed $(5 \mathrm{~g} / \mathrm{bag})$ into nylon bags $(10 \mathrm{~cm} \times 20 \mathrm{~cm}$, $50 \mu \mathrm{m}$ pore size, ANKOM Technology, Macedon, NY, USA). Duplicate bags containing respective substrates were incubated in the rumen of each heifer for $2,6,12$, 24, 48, 72 and $96 \mathrm{~h}$. Nylon bags were placed into large mesh bags $(20 \mathrm{~cm} \times 30 \mathrm{~cm})$ and soaked in warm water $\left(39^{\circ} \mathrm{C}\right.$ ) for $10 \mathrm{~min}$ prior to placement in the rumen. The nylon bags in mesh bags were inserted into the rumen 
in reverse order of incubation time so that all bags were removed simultaneously after incubation. The removed bags from the rumen were immediately rinsed under cold running tap water till the rinse water was clear and subsequently washed in a washing machine for $2 \mathrm{~min}$ without detergent or the use of the spin cycle. The $0 \mathrm{~h}$ bags were not incubated in the rumen, but were washed using the same protocol. All bags with residue were subsequently dried at $55^{\circ} \mathrm{C}$ for $48 \mathrm{~h}$ and weighed to determine DM disappearance. Residues from duplicate bags of each sample incubated in the same heifer were pooled and ground to pass through a $1 \mathrm{~mm}$ screen for determinations of aNDF and CP disappearance [18].

\section{Laboratory analysis}

Dry matter was determined by drying samples at $105^{\circ} \mathrm{C}$ for $16 \mathrm{~h}$ in a forced-air oven (AOAC, \# 930.15) [19] and organic matter $(\mathrm{OM})$ was determined by ashing in a muffle furnace (AOAC, \# 943.01) [19]. The samples were ball ground in a planetary micro mill (Retsch Inc., Newtown, PA, USA) and analyzed for total $\mathrm{N}$ estimation by flash combustion analysis using a NA1500 nitrogen analyzer (Carlo Erba Instruments, MI, Italy). Neutral detergent fibre and acid detergent fibre (ADF) were performed using an Ankom 200 system (Ankom Technology Corp., Fairport, NY, USA), with addition of sodium sulfite and alphaamylase for aNDF but without for ADF analysis as described by McGinn et al. [20], and the residual ash was included in the aNDF calculation. The concentrations of extractable CT (ECT) of forage samples were determined using method described by Terrill et al. [21] with purified PPC CT used as a standard [22].

\section{Calculation and statistical analysis}

In situ DM, aNDF and CP disappearances were determined as the difference in substrate weight before and after ruminal incubation. The kinetics of in situ DM, aNDF and CP disappearance were estimated using a non-linear regression procedure of SAS (SAS Institute Inc., Cary, NC, USA) using the equation described by McDonald [23]:

$P=a+b\left(1-\mathrm{e}^{-c(\mathrm{t}-L)}\right)$ where $P=$ ruminal disappearance at time $t(\%), a=$ the rapidly soluble degradable fraction (\%), $b=$ the slowly or potentially degradable fraction (\%), $a+b=$ the maximum potential degradability, $c=$ the rate at which $b$ is degraded $(\% / \mathrm{h}), t=$ time (h) incubation in the rumen, and $L=$ lag time (h).

Effective degradabilities (ED) of DM, aNDF and CP were estimated using the equation described by Orskov and McDonald [24]:

$\mathrm{ED}=a+[b c /(c+k)] \mathrm{e}^{-(\mathrm{c}+k) L}$ with $a, b, c$ and $L$ as described above and $k=$ the ruminal outflow rate $(\% / \mathrm{h})$, which was set at 0.02 for aNDF and 0.05 for both DM and CP [25]. The constants $a, b, c$ and $L$ for each animal were calculated using nonlinear regression procedures of
SAS [26]. The degradability of CP for the mixture of 0 : 100 (PPC: grasses) could not be estimated due to the very low $\mathrm{N}$ content in these samples and thereby was excluded from the final analysis.

All data were analyzed using the MIXED procedure of SAS. Chemical compositional data were analyzed using one-way ANOVA with maturity as fixed effect and forage pasture as a random factor. Data from the in vitro and in situ studies were analyzed by completely randomized design model. Forage mixture ratio, PPC maturity and their interaction were the fixed effects and run was treated as a random factor in the analysis of in vitro data, whereas either forage mixture ratio or PPC maturity was considered as fixed effects and cow was treated as a random factor in analysis of in situ experiment data. Disappearances of DM, aNDF and CP were also analyzed at each incubation time. Orthogonal polynomial contrasts were used to determine linear and quadratic responses to the levels of PPC in the forage mixtures. The parameters calculated from the in situ DM, aNDF and CP disappearance data, were analyzed using MIXED model procedure of SAS using the following model:

$y_{i j}=\mu+\alpha_{i}+\beta_{j}+\varepsilon_{i j}$ where $y_{i j}$ is the parameter, $\mu$ is the overall mean, $\alpha_{i}$ is the effect of heifer (1-3), $\beta_{j}$ is the effect of treatment, and $\varepsilon_{i j}$ is the residual error.

Differences between treatments means was determined by the PDIFF option of LSMEANS in SAS and declared significant at $P<0.05$.

\section{Results}

Chemical characteristics of PPC and cool-season grasses at different maturities

In general, PPC was numerically lower in aNDF and $\mathrm{ADF}$, but higher in $\mathrm{CP}$ than the grasses (Table 1). Contents of aNDF and ADF increased $(P<0.01)$ but CP decreased $(P<0.001)$ with advancing maturity of PPC. In contrast, these changes over the same sampling period were not as obvious for cool-season grasses, likely because these grasses were cool-season grasses that had already reached physiological maturity. Concentration of ECT in PPC was highest $(P<0.01)$ at FL, followed by VEG and SP, respectively $(P<0.05)$. Condensed tannins were not detected in any of the mixed grass samples.

\section{In vitro ruminal fermentation characteristics of PPC and} grass mixtures at different maturities

Fermentation of the PPC-grass mixtures differed with changes in the amount of PPC in the mixtures as well as maturity (Tables 2 and 3, Fig. 1). With increasing concentrations of PPC, IVDMD linearly increased $(P<0.001)$ at VEG, but linearly decreased $(P<0.001)$ at SP (Table 2$)$. Dry matter disappearance was also quadratically increased $(P<0.05)$ as the VEG PPC increasing in the mixture. However, these differences were not observed for GP and 
Table 1 Chemical composition (g/kg DM) of purple prairie clover (PPC; Dalea purpurea Vent.) and cool-season native grasses that were harvested when PPC reached vegetative (VEG), full flower (FL) and seedpod (SP) stages

\begin{tabular}{|c|c|c|c|c|c|c|c|c|c|c|}
\hline \multirow[t]{2}{*}{ Item $^{e}$} & \multicolumn{3}{|l|}{ PPC } & \multirow[t]{2}{*}{ SEM } & \multirow[t]{2}{*}{$P$-value } & \multicolumn{3}{|l|}{ Grass } & \multirow[t]{2}{*}{ SEM $^{d}$} & \multirow{2}{*}{$\begin{array}{l}P \text { - } \\
\text { value }\end{array}$} \\
\hline & VEG & $\mathrm{FL}$ & $\mathrm{SP}$ & & & VEG & $\mathrm{FL}$ & SP & & \\
\hline$\overline{\mathrm{OM}}$ & 931.9 & 939.3 & 929.6 & 4.70 & 0.421 & $926.9^{b}$ & $928.5^{b}$ & $939.5^{a}$ & 1.74 & 0.026 \\
\hline aNDF & $438.3^{b}$ & $526.1^{a}$ & $547.8^{\mathrm{a}}$ & 5.64 & 0.002 & 738.5 & 748.7 & 757.4 & 7.27 & 0.323 \\
\hline ADF & $349.8^{c}$ & $497.1^{\mathrm{b}}$ & $534.0^{\mathrm{a}}$ & 6.89 & $<0.001$ & 507.2 & 516.8 & 509.6 & 2.80 & 0.067 \\
\hline$C P$ & $137.8^{\mathrm{a}}$ & $99.7^{b}$ & $83.4^{c}$ & 0.75 & $<0.001$ & $37.5^{\mathrm{a}}$ & $29.4^{b}$ & $35.1^{\mathrm{a}}$ & 0.44 & 0.009 \\
\hline ECT & $65.7^{\mathrm{b}}$ & $87.2^{\mathrm{a}}$ & $50.4^{c}$ & 1.67 & $<0.001$ & ND & ND & ND & - & - \\
\hline
\end{tabular}

$\overline{a, b, c}$ Means with different superscript letters in the same row differ $(P<0.05)$

${ }^{d}$ SEM standard error of the means $(n=4)$

${ }^{\mathrm{e}} \mathrm{OM}$ organic matter, aNDF neutral detergent fibre (the residual ash was included in the aNDF calculation), $A D F$ acid detergent fibre, $C P$ crude protein (N $\times 6.25$ ),

$E C T$ extractable condensed tannins, ND not detectable

total VFA when forages were at the FL stage. When plants were at the VEG stage, GP linearly increased $(P<0.01)$ over the 48-h incubation with increasing PPC in the mixture (Fig. 1a). However, this linear increase was observed only during the early periods (i.e., 3, 6, 9 and $12 \mathrm{~h}$ ) of incubation at the FL and SP stages (Fig. 1b, c).

Ammonia-N accumulation after 48 -h incubation was affected by maturity $(P<0.05)$ and proportion $(P<0.001)$ of PPC. Regardless of PPC proportion, incubation of plants at the VEG stage resulted in higher $(P<0.05)$ ammonia-N accumulation than either FL or SP stages. Increasing PPC in the mixtures linearly increased $(P<$ $0.001)$ ammonia- $\mathrm{N}$ accumulation at all maturities. Regression showed that irrespective of PPC maturity, there was a linear increase $(P<0.01)$ in in vitro ammonia- $\mathrm{N}$ with increased $\mathrm{N}$ content of the substrate as the result of increasing levels of PPC in the mixtures (Fig. 2).

The effects of plant maturity and proportion of PPC in the mixture and their interaction on total VFA production were consistent with their effects on GP and IVDMD (Table 3). As PPC increased, total VFA production linearly increased $(P<0.001)$ at the VEG stage, but linearly decreased $(P<0.001)$ at the SP stage. For all three maturities, increasing PPC linearly increased $(P<$ $0.001)$ molar percentage of acetate and branched-chain VFA, but linearly decreased $(P<0.001)$ molar percentage of propionate, resulting in a linear increase $(P<0.001)$ in the acetate: propionate ratio. With plants harvested at FL and SP stages, molar percentage of butyrate linearly decreased $(P<0.01)$ as PPC in the mixture increased.

\section{In situ ruminal degradation characteristics of PPC and grass mixtures at different maturities}

Dry matter disappearance linearly increased $(P<0.001)$ as PPC increased with difference being significant $(P<0.01)$ up to $72 \mathrm{~h}$ of ruminal incubation (Fig. 3a). However, all substrates exhibited similar DM disappearance after $96 \mathrm{~h}$ of incubation. The disappearance of aNDF in all substrates at $0,2,6$ and $12 \mathrm{~h}$ followed the similar trend to DM disappearance (Fig. 3b). In contrast, after $72 \mathrm{~h}$, aNDF disappearance linearly decreased $(P<0.001)$ as PPC increased and the difference among substrates was significant $(P<$ $0.001)$ after $96 \mathrm{~h}$ of incubation. The ranking of disappearance of $\mathrm{CP}$ among different substrates differed at the early

Table 2 In vitro dry matter disappearance (IVDMD, mg/g DM) and ammonia-N accumulation (mmol/L) after 48-h in vitro ruminal fermentation of purple prairie clover (PPC; Dalea purpurea Vent.) and cool-season native grasses that were harvested when PPC reached the vegetative (VEG), full flower (FL) and seedpod (SP) stages and combined at different ratios

\begin{tabular}{|c|c|c|c|c|c|c|c|c|c|c|c|}
\hline \multirow{2}{*}{$\begin{array}{l}\text { Maturity } \\
\text { (M) }\end{array}$} & \multicolumn{5}{|c|}{ PPC percentage (PP) } & \multirow[t]{2}{*}{ SEM $^{e}$} & \multicolumn{5}{|c|}{$P$ values $^{f}$} \\
\hline & 0 & 25 & 50 & 75 & 100 & & $\mathrm{M}$ & PP & $\mathrm{M} \times \mathrm{PP}$ & L & Q \\
\hline & \multicolumn{11}{|c|}{ IVDMD } \\
\hline VEG & $564^{d}$ & $604^{c}$ & $590^{c d}$ & $635^{\mathrm{b}}$ & $705^{\mathrm{a}}$ & 35.9 & $<0.001$ & $<0.001$ & $<0.001$ & $<0.001$ & 0.015 \\
\hline $\mathrm{FL}$ & $512^{\mathrm{a}}$ & $509^{a}$ & $463^{b}$ & $471^{\mathrm{b}}$ & $469^{b}$ & & & & & 0.001 & 0.161 \\
\hline \multirow[t]{2}{*}{ SP } & $571^{a}$ & $561^{a}$ & $507^{b}$ & $475^{c}$ & $440^{d}$ & & & & & $<0.001$ & 0.728 \\
\hline & \multicolumn{11}{|c|}{ Ammonia-N } \\
\hline VEG & $5.43^{e}$ & $6.00^{d}$ & $6.72^{c}$ & $7.23^{b}$ & $8.00^{\mathrm{a}}$ & 0.293 & 0.049 & $<0.001$ & 0.731 & $<0.001$ & 0.772 \\
\hline $\mathrm{FL}$ & $4.74^{c}$ & $5.31 b^{c}$ & $5.74^{b}$ & $6.59^{\mathrm{a}}$ & $6.87^{\mathrm{a}}$ & & & & & $<0.001$ & 0.863 \\
\hline SP & $4.87^{c}$ & $5.53^{b}$ & $5.92^{b}$ & $6.49^{a}$ & $6.71^{a}$ & & & & & $<0.001$ & 0.436 \\
\hline
\end{tabular}

a,b,c,d Means with different superscript letters in the same row differ $(P<0.05)$

eSEM standard error of the means

${ }^{f} L$ linear, $Q$ quadratic, These are linear and quadratic contrasts across PPC percentages within PPC maturity 
Table 3 Total volatile fatty acids (VFA) concentrations and individual VFA profiles after $48 \mathrm{~h}$ of in vitro ruminal fermentation of purple prairie clover (PPC; Dalea purpurea Vent.) and cool-season native grasses that were harvested when PPC reached the vegetative (VEG), full flower (FL) and seedpod (SP) stages and combined at different ratios

\begin{tabular}{|c|c|c|c|c|c|c|c|c|c|c|c|}
\hline \multirow{2}{*}{$\begin{array}{l}\text { Maturity } \\
\text { (M) }\end{array}$} & \multicolumn{5}{|c|}{ PPC percentage (PP) } & \multirow[t]{2}{*}{ SEM $^{e}$} & \multicolumn{5}{|l|}{$P$ values ${ }^{f}$} \\
\hline & 0 & 25 & 50 & 75 & 100 & & $\bar{M}$ & PP & $M \times P P$ & $\mathrm{~L}$ & Q \\
\hline & \multicolumn{11}{|c|}{ Total VFA, mmol/L } \\
\hline VEG & $32.4^{c}$ & $35.9^{\mathrm{b}}$ & $33.5^{b c}$ & $33.7^{\mathrm{bc}}$ & $40.0^{\mathrm{a}}$ & 1.44 & $<0.001$ & 0.001 & $<0.001$ & $<0.001$ & 0.020 \\
\hline $\mathrm{FL}$ & 28.1 & 24.4 & 26.0 & 26.5 & 27.5 & & & & & 0.306 & 0.215 \\
\hline \multirow[t]{2}{*}{ SP } & $26.7^{a}$ & $26.2^{a}$ & $23.9^{b}$ & $23.1^{b c}$ & $21.9^{c}$ & & & & & $<0.001$ & 0.723 \\
\hline & \multicolumn{11}{|c|}{ Acetate (A), \% of the total VFA } \\
\hline VEG & $59.4^{c}$ & $60.6^{c}$ & $62.4^{\mathrm{b}}$ & $63.0^{\mathrm{b}}$ & $65.4^{\mathrm{a}}$ & 0.63 & 0.004 & $<0.001$ & 0.001 & $<0.001$ & 0.569 \\
\hline $\mathrm{FL}$ & $58.9^{e}$ & $61.3^{d}$ & $65.2^{c}$ & $67.3^{b}$ & $69.8^{\mathrm{a}}$ & & & & & $<0.001$ & 0.457 \\
\hline \multirow[t]{2}{*}{ SP } & $59.2^{c}$ & $60.7^{c}$ & $64.7^{b}$ & $65.1^{b}$ & $67.7^{\mathrm{a}}$ & & & & & $<0.001$ & 0.601 \\
\hline & \multicolumn{11}{|c|}{ Propionate $(\mathrm{P}), \%$ of the total VFA } \\
\hline VEG & $32.0^{\mathrm{a}}$ & $29.3^{b}$ & $28.0^{\mathrm{bc}}$ & $26.9^{c}$ & $24.2^{d}$ & 0.43 & 0.122 & $<0.001$ & 0.008 & $<0.001$ & 0.954 \\
\hline $\mathrm{FL}$ & $33.5^{\mathrm{a}}$ & $30.1^{b}$ & $26.7^{c}$ & $25.2^{d}$ & $23.3^{e}$ & & & & & $<0.001$ & 0.001 \\
\hline \multirow[t]{2}{*}{ SP } & $32.6^{a}$ & $30.5^{b}$ & $27.8^{c}$ & $26.4^{d}$ & $24.3^{e}$ & & & & & $<0.001$ & 0.258 \\
\hline & \multicolumn{11}{|c|}{ Butyrate, $\%$ of the total VFA } \\
\hline VEG & $7.6^{\mathrm{b}}$ & $8.4^{\mathrm{ab}}$ & $8.3^{\mathrm{ab}}$ & $8.4^{\mathrm{ab}}$ & $8.5^{\mathrm{a}}$ & 0.57 & $<0.001$ & $<0.001$ & $<0.001$ & 0.096 & 0.261 \\
\hline $\mathrm{FL}$ & $7.4^{\mathrm{ab}}$ & $7.8^{\mathrm{a}}$ & $6.9^{b}$ & $5.9^{c}$ & $5.3^{c}$ & & & & & $<0.001$ & 0.073 \\
\hline \multirow[t]{2}{*}{ SP } & $7.8^{\mathrm{a}}$ & $7.9^{a}$ & $6.8^{\mathrm{b}}$ & $7.3^{\mathrm{ab}}$ & $6.5^{\mathrm{b}}$ & & & & & 0.006 & 0.872 \\
\hline & \multicolumn{11}{|c|}{ Branch-chained VFA, \% of the total VFA } \\
\hline VEG & $1.1^{\mathrm{c}}$ & $1.6^{\mathrm{ab}}$ & $1.3^{\mathrm{bc}}$ & $1.7^{\mathrm{ab}}$ & $1.9^{\mathrm{a}}$ & 0.14 & $<0.001$ & $<0.001$ & 0.284 & 0.006 & 0.907 \\
\hline $\mathrm{FL}$ & $0.3^{c}$ & $0.9^{b}$ & $1.2^{\mathrm{b}}$ & $1.5^{\mathrm{a}}$ & $1.6^{\mathrm{a}}$ & & & & & $<0.001$ & 0.015 \\
\hline \multirow[t]{2}{*}{ SP } & $0.4^{c}$ & $0.9^{b}$ & $0.9^{\mathrm{b}}$ & $1.3^{\mathrm{a}}$ & $1.5^{\mathrm{a}}$ & & & & & $<0.001$ & 0.603 \\
\hline & \multicolumn{11}{|c|}{ A:P ratio } \\
\hline VEG & $1.87^{\mathrm{d}}$ & $2.08^{c}$ & $2.24^{\mathrm{bc}}$ & $2.36^{\mathrm{b}}$ & $2.72^{\mathrm{a}}$ & 0.057 & 0.102 & $<0.001$ & $<0.001$ & $<0.001$ & 0.236 \\
\hline $\mathrm{FL}$ & $1.76^{\mathrm{e}}$ & $2.04^{d}$ & $2.44^{c}$ & $2.70^{\mathrm{b}}$ & $3.00^{\mathrm{a}}$ & & & & & $<0.001$ & 0.567 \\
\hline SP & $1.82^{e}$ & $1.99^{d}$ & $2.33^{c}$ & $2.47^{b}$ & $2.81^{a}$ & & & & & $<0.001$ & 0.397 \\
\hline
\end{tabular}

a,b,c,d Means with different superscript letters in the same row differ $(P<0.05)$

${ }^{\text {e}} \mathrm{SEM}$ : standard error of the means

${ }^{f} L$ linear, $Q$ quadratic, These are linear and quadratic contrasts across PPC percentages within PPC maturity

hours (2, 12 and $24 \mathrm{~h}$ ) of incubation (Fig. 4a). However, disappearance of $\mathrm{CP}$ after $24 \mathrm{~h}$ linearly increased $(P<0.001)$ with increasing PPC. The change of $\mathrm{N}$ content of the residues over $96-\mathrm{h}$ ruminal incubation differed among substrates (Fig. 4b). However, all substrates had similar residual $\mathrm{N}$ content at $96 \mathrm{~h}$ of incubation.

Increasing FL PPC in the mixture linearly and quadratically $(P<0.01)$ increased $a$ fraction of DM and aNDF, but linearly and quadratically decreased $(P<$ $0.01)$ the $b$ fraction, resulting in a linear $(P<0.05)$ and quadratic $(P<0.01)$ decrease in DM and aNDF degradability $(a+b$, Table 4$)$. However, the degradation rate $(c)$ of the $b$ fraction was linearly and quadratically increased $(P<0.01)$ for both DM and aNDF with increasing PPC. Effective degradabilities of DM and aNDF were linearly and quadratically increased
$(P<0.05)$, and $\mathrm{CP}$ was quadratically increased $(P<$ $0.05)$ with increasing FL PPC, with the greatest effective degradability being observed with PPC:grass ratios between 50:50 and 75:25.

Ruminal degradabilities of DM, aNDF and $\mathrm{CP}$ decreased $(P<0.01)$ as the PPC matured (Fig. 5a, b, c and Table 5). The decreases in DM and aNDF degradability were mainly observed between the FL to SP stage. However, CP degradability decreased to a similar extent with advancing maturity.

Degradation kinetic parameters showed similar trends. Forages harvested at VEG and FL had similar $a, b$ and $a+b$ fractions of DM and aNDF, and both were greater $(P<0.05)$ than that harvested at the SP stage (Table 5). Effective degradability of DM ranked as VEG $>\mathrm{FL}>\mathrm{SP}(P<0.001)$, whereas the ED of aNDF was similar between VEG and FL and both were 
(a)

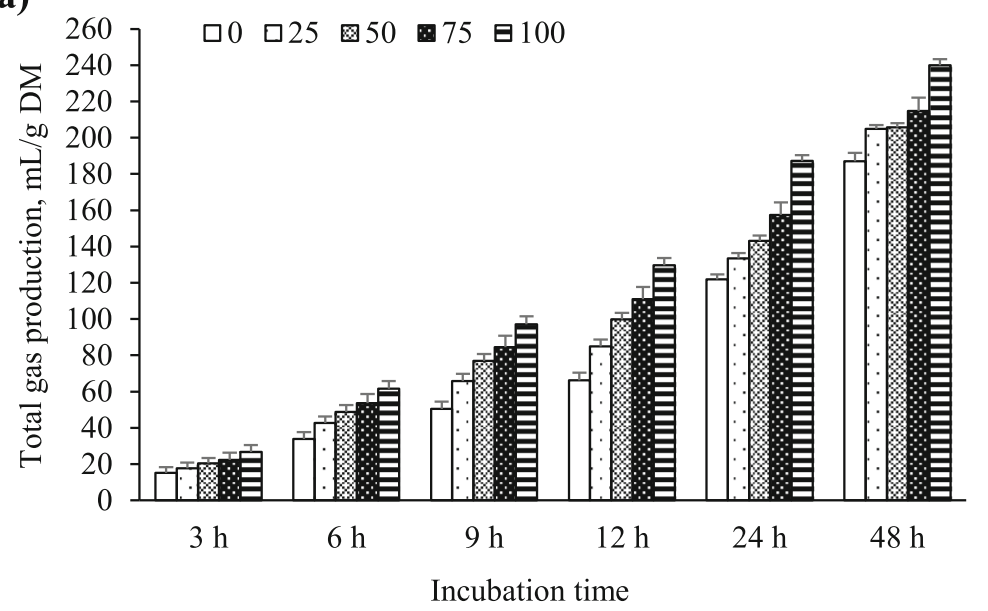

(b)

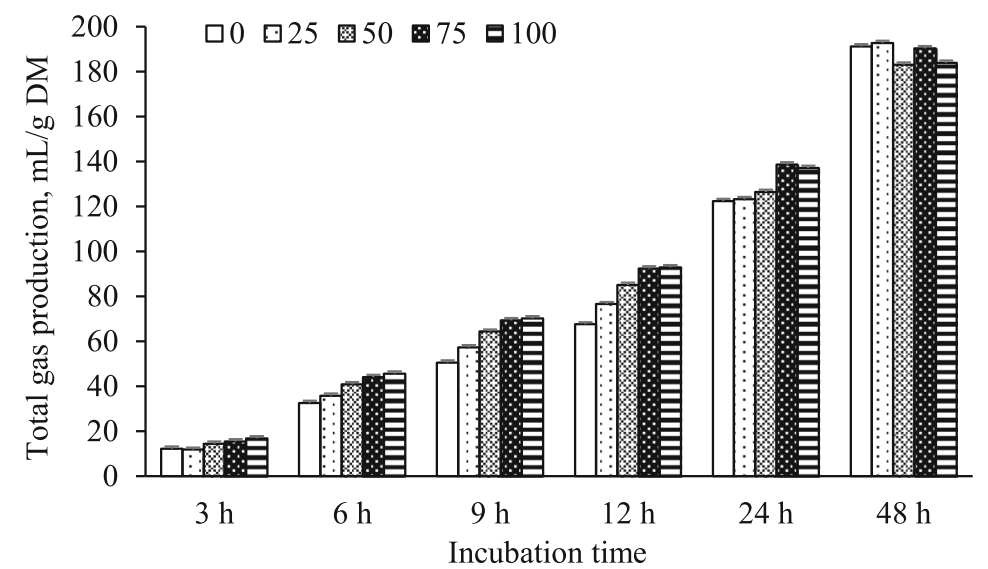

(c)

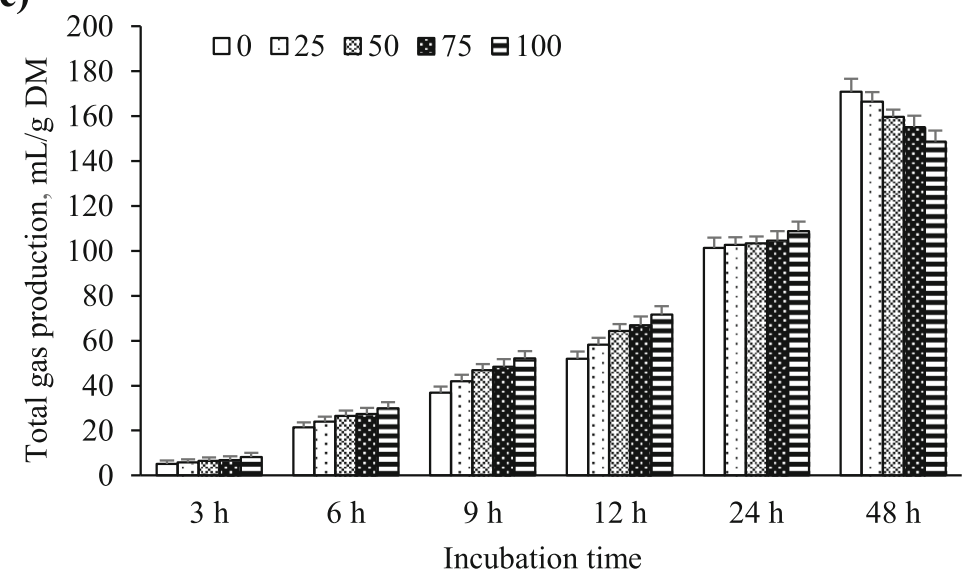

Fig. 1 Total gas production during 48-h in vitro ruminal incubation of different ratios of purple prairie clover (PPC; Dalea purpurea Vent.) and cool-season grasses that were harvested when PPC reached the vegetative (a), full flower $(\mathbf{b})$ and seedpod (c) stages

greater $(P<0.01)$ than SP. Forages harvested at VEG, FL and SP had similar soluble fraction $(a)$ of protein, but the potential degradable fraction $(b)$ of protein was greater $(P<0.01)$ for forage harvested at the VEG than the SP stage.

\section{Discussion}

The higher aNDF and ADF contents but lower CP content of cool-season grasses as compared to PPC across all maturities indicated that nutritional quality of PPC was superior to mature cool-season grasses. Therefore, 


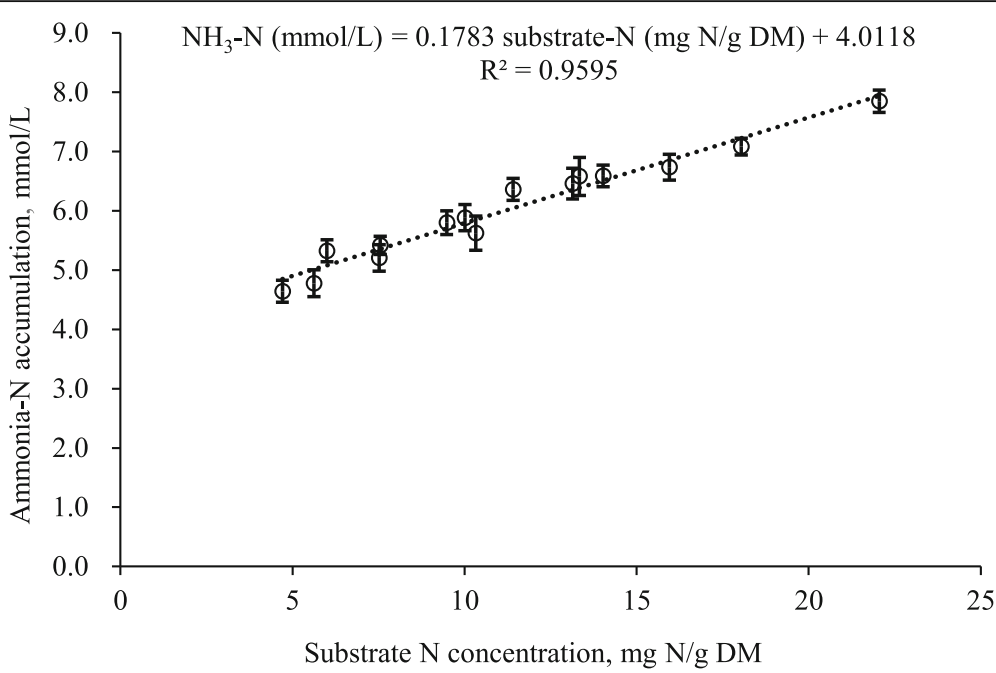

Fig. 2 Relationship between ammonia- $N$ accumulation at 48-h in vitro incubation and substrate $\mathrm{N}$ concentration of mixtures of purple prairie clover (PPC; Dalea purpurea Vent.) and cool-season grasses that were harvested when PPC reached the vegetative, full flower and seedpod stages

incorporation of PPC into cool-season grass pasture would increase the forage quality of rehabilitated native pasture. However, the increased aNDF and ADF but decreased CP content of PPC with advancing maturity indicates that the nutritive value of PPC decreased as it matured. This compared with the observation that coolseason grasses had relatively similar aNDF, ADF and CP contents during the same period of growth indicated that the PPC and cool-season grass mixture had a higher nutritive value when PPC was in the vegetative stage. The nutrient composition of PPC at VEG and FL were comparable to that reported by Jin et al. [11]. Generally, with advancing maturity, forage quality declines as fibre content increases and protein concentration decreases [27]. The increased fibre content in whole plant PPC with advancing maturity was likely due to increased fibre concentration in stem and an increase in the stem: leaf ratio [11]. Reduced protein content in PPC as the plant matures was also reported by Posler et al. [28]. Nevertheless, the higher protein concentration of PPC throughout the growing season as compared to cool-season grasses suggests that PPC could be a valuable $\mathrm{N}$ source in rehabilitated native pasture. Others have concluded that PPC in the vegetative and flower stages are good quality forages for ruminants [29] as the fibre and CP contents are similar to other common legumes such as alfalfa and sainfoin harvested at the same growth stages [30].

Changes in CT concentration in PPC with advancing maturity were similar to that reported by Jin et al. [11]. The finding that the ECT in PPC was higher in FL but lower in SP as compared to VEG stage was also consistent with the observations of $\mathrm{Li}$ et al. [31]. This was mainly attributable to the higher proportion of flowers in FL and more stems in SP than VEG [11, 30, 32]. As PPC matures, the ECT concentration decreases in stem, but remains relatively constant in the leaves and flowers [32].

Gas and VFA are major products of microbial fermentation of diets in the rumen and therefore the changes of gas and VFA production due to plant maturity and PPC proportions in the forage mixtures were positively related to IVDMD in this study. The in vitro study showed that PPC at VEG stage had greater DM digestibility, resulting in greater GP and total VFA production than cool-season grasses. However, as PPC matured to the FL and SP stages, IVDMD, GP and total VFA production were dramatically decreased, a response that was less apparent for cool-season grasses. This combined with the same trend of nutrient composition changes of the two forages from VEG to SP indicated that digestible DM of PPC at VEG stage was higher than that of cool-season grasses, whereas the reverse occurred when PPC reached the SP stage because of the faster decline in digestible DM during transition from VEG to SP stage. These differential changes of digestible DM content between the two forages as the plant maturity advanced impacted the nutritive values of their mixtures at different maturities, resulting in plant maturity $\times$ PPC proportion interaction. However, it needs to be pointed out that in real field conditions it is not always possible to attain the desirable ratio between legume and grasses and to synchronize their stages of maturity at the time of cutting. The IVDMD, GP and total VFA production demonstrated that increasing VEG PPC in the mixtures linearly increased ruminal fermentation, but it was decreased by increasing SP PPC. In contrast, the relatively similar IVDMD, GP and total VFA of FL PPC-grass mixtures indicated that PPC and cool-season grasses were fermented to a similar degree at this stage. The decline 


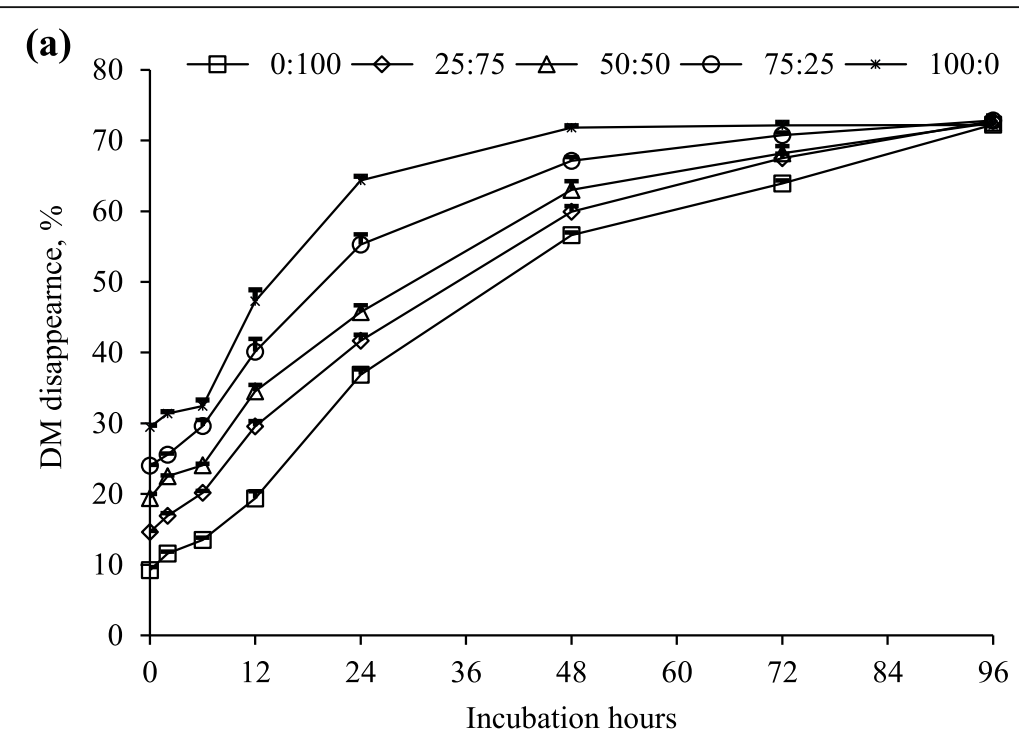

(b)

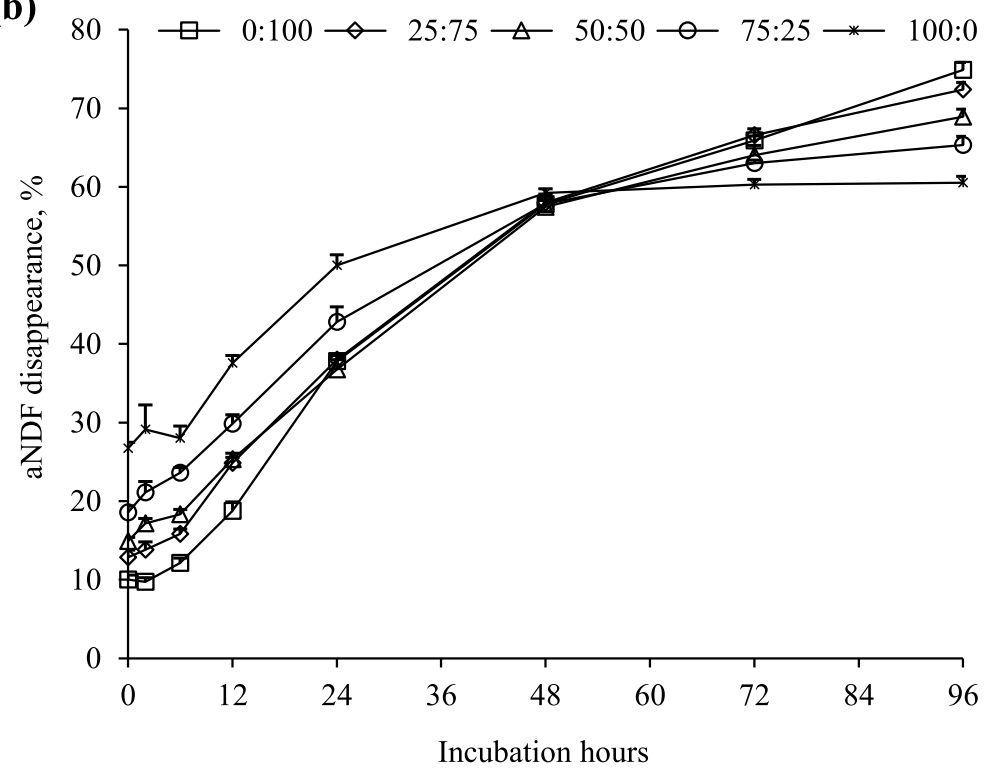

Fig. 3 Disappearances of dry matter (DM, a) and neutral detergent fibre (aNDF, b) during 96-h incubation of mixtures of purple prairie clover (PPC; Dalea purpurea Vent.) and cool-season grasses in ratios of 0:100, 25:75, 50:50, 75:25 and 100:0. Both PPC and grass were harvested when PPC reached full flower stage

in ruminal digestion of PPC and cool-season grasses from VEG to SP was supported by the in situ results which found that the ruminal degradabilities of DM, aNDF and CP in 50:50 PPC-grass mixture all declined with advancing PPC maturity. Others have also observed reduced ruminal degradation of DM and $\mathrm{CP}$ with advancing PPC maturity $[11,28]$. Altogether, the in vitro ruminal digestion and productions of total VFA and gas suggest that PPC is likely to result in the greatest improvement in mixed forages when it is at the vegetative and full flower stages.

The reduction in the ruminal fermentation of PPC and cool-season grasses from vegetative to seedpod stages was reflected in the increase in ADF content of the two forages. Negative effect of ADF content on forage digestion has been demonstrated in literature [33]. Interestingly, almost all measurements in the in vitro experiment in this study showed linear but not quadratic responses to the proportions of PPC in the mixtures. This indicated that there was no associative effect of combining PPC and cool-season grasses on the nutritive value as observed in legume [red clover (Trifolium pratense L.) and white clover (Trifolium repens $\mathrm{L}$.)]-grass (timothy (Phleum pratense L.) and smooth meadow grass (Poa pratensis L.) mixed forages [34]. A quadratic response in DM, NDF and CP effective degradabilities to increasing PPC was observed 


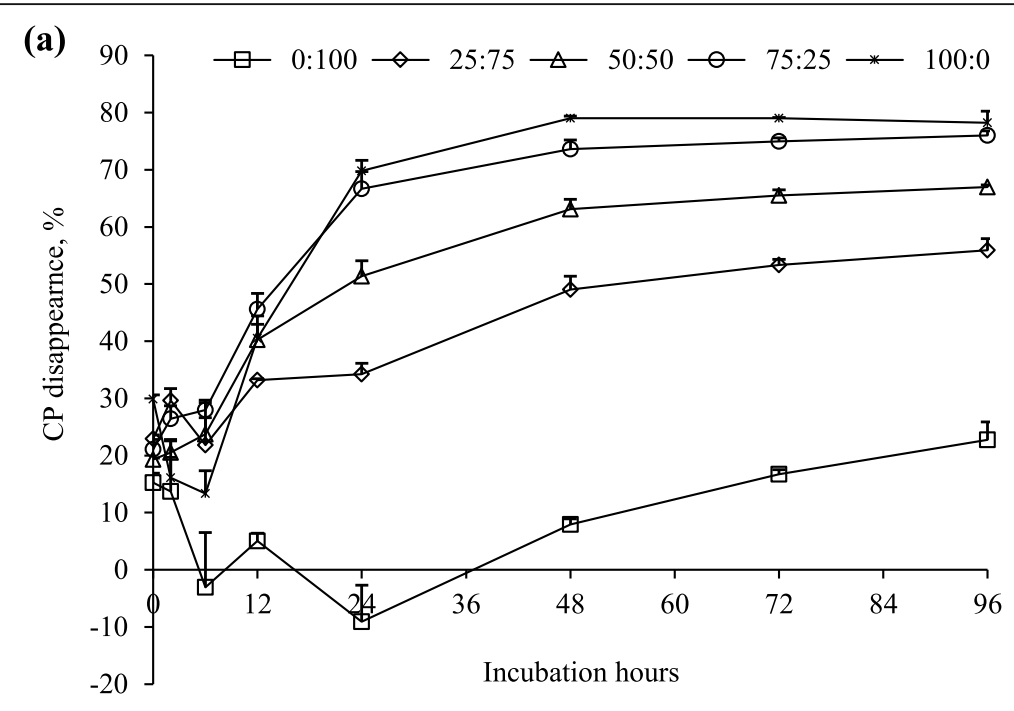

(b)

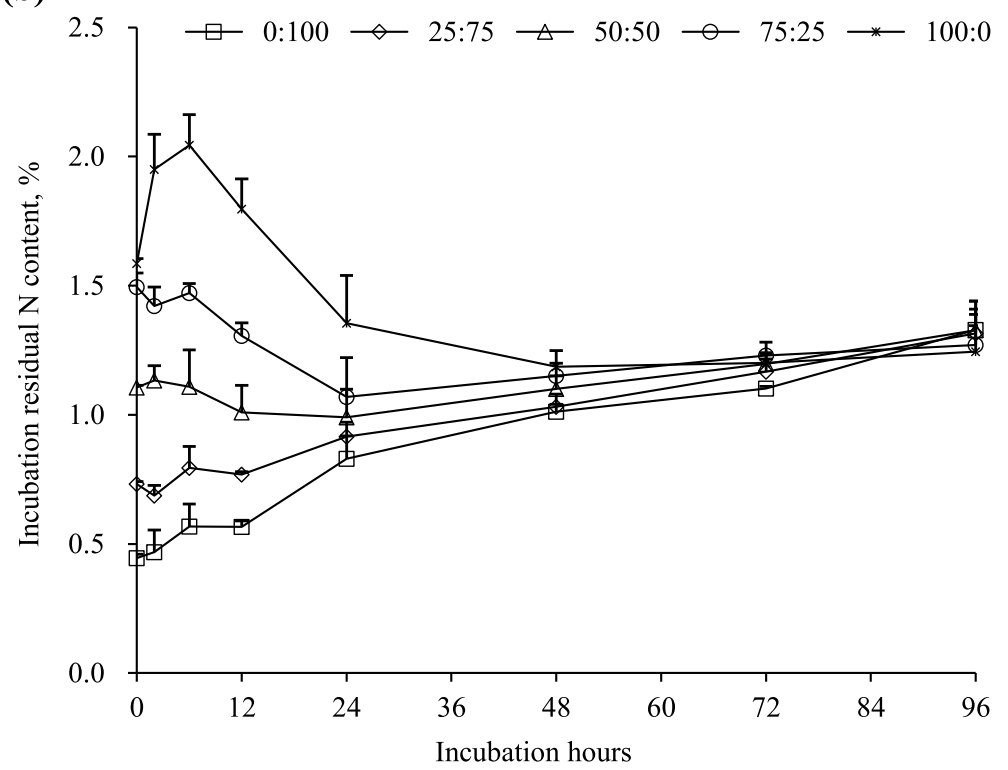

Fig. 4 Disappearance of crude protein (CP, a) and residual N content (b) during 96-h incubation of mixtures of purple prairie clover (PPC; Dalea purpurea Vent.) and cool-season grasses in ratios of 0:100, 25:75, 50:50, 75:25 and 100:0. Both PPC and grasses were harvested when PPC reached the full flower stage

with them plateauing when FL PPC was included in the mixture at $75 \%$. However, there were not statistical differences between $75 \%$ PPC mixture and pure PPC or other PPC-grass mixtures (aNDF and CP). This also suggested that there was no positive associative effect of mixing cool-season grass and PPC on DM, aNDF and CP effective degradability when full flower PPC was mixed with coolseason grasses. This phenomenon was largely associated with the lower $\mathrm{ADF}$ and higher $\mathrm{CP}$ contents in the full flower PPC than in cool-season grass. Dal Pizzol et al. [7] reported positive associative effects on in vitro fermentation as a result of mixing a tropical grass (axonopus,
Axonopus catharinenses) and a temperate legume (alfalfa, Medicago sativa) but not between peanut vines (Arachis pintoi), sainfoin (Onobrychis viciifolia) and grasses of axonopus and tall fescue (Festuca arundinacea).

Crude protein content in PPC was higher than that in cool-season grasses throughout the growing season. This resulted in an increase in the protein concentrations of the PPC-grass mixtures and the subsequent increase in ammonia- $\mathrm{N}$ concentration during in vitro fermentation. Ammonia- $\mathrm{N}$ accumulation in closed in vitro system is the net result of ammonia from the degradation of dietary protein and utilization by microbes for microbial 
Table 4 In situ ruminal degradation characteristics of dry matter (DM), neutral detergent fiber (aNDF), and crude protein (CP) disappearance of mixtures of purple prairie clover (PPC; Dalea purpurea Vent.) and cool-season grasses in ratios of 0:100, 25:75, 50:50, 75:25 and 100:0. Both PPC and grass were harvested when PPC reached the full flower stage

\begin{tabular}{|c|c|c|c|c|c|c|c|c|c|}
\hline \multirow[t]{2}{*}{ Items $^{9}$} & \multirow[t]{2}{*}{$0: 100$} & \multirow[t]{2}{*}{$25: 75$} & \multirow[t]{2}{*}{$50: 50$} & \multirow[t]{2}{*}{$75: 25$} & \multirow[t]{2}{*}{ 100:0 } & \multirow[t]{2}{*}{$\mathrm{SEM}^{e}$} & \multicolumn{3}{|c|}{$P$ values $^{f}$} \\
\hline & & & & & & & $P$ & $L$ & Q \\
\hline \multicolumn{10}{|l|}{$\overline{\mathrm{DM}}$} \\
\hline$a+b$ & $75.0^{\mathrm{ab}}$ & $79.3^{\mathrm{a}}$ & $77.6^{\mathrm{a}}$ & $74.8^{\mathrm{ab}}$ & $72.5^{\mathrm{b}}$ & 1.20 & 0.009 & 0.029 & 0.01 \\
\hline$a$ & $10.4^{\mathrm{e}}$ & $14.3^{d}$ & $18.3^{c}$ & $21.8^{\mathrm{b}}$ & $30.5^{\mathrm{a}}$ & 0.39 & $<0.001$ & $<0.001$ & $<0.001$ \\
\hline$b$ & $64.6^{\mathrm{ab}}$ & $65.0^{\mathrm{a}}$ & $59.3^{b}$ & $53.0^{c}$ & $42.0^{d}$ & 1.27 & $<0.001$ & $<0.001$ & $<0.001$ \\
\hline c & $2.79^{b}$ & $2.46^{\mathrm{b}}$ & $2.65^{b}$ & $3.83^{b}$ & $9.14^{\mathrm{a}}$ & 0.476 & $<0.001$ & $<0.001$ & $<0.001$ \\
\hline Lag & $5.1^{\mathrm{a}}$ & $1.2^{\mathrm{b}}$ & $0.0^{b}$ & $0.0^{\mathrm{b}}$ & $6.0^{\mathrm{a}}$ & 0.62 & $<0.001$ & $<0.001$ & 0.757 \\
\hline$E D_{0.05}$ & $25.9^{d}$ & $34.0^{c}$ & $38.8^{\mathrm{b}}$ & $44.6^{\mathrm{a}}$ & $42.0^{\mathrm{ab}}$ & 0.86 & $<0.001$ & $<0.001$ & $<0.001$ \\
\hline \multicolumn{10}{|l|}{ aNDF } \\
\hline$a+b$ & $79.9^{\mathrm{a}}$ & $80.2^{\mathrm{a}}$ & $80.8^{\mathrm{a}}$ & $70.7^{\mathrm{b}}$ & $61.6^{c}$ & 1.15 & $<0.001$ & $<0.001$ & $<0.001$ \\
\hline$a$ & $10.1^{c}$ & $12.4^{\mathrm{bc}}$ & $13.2^{\mathrm{bc}}$ & $17.2^{\mathrm{b}}$ & $26.5^{\mathrm{a}}$ & 1.23 & $<0.001$ & $<0.001$ & 0.008 \\
\hline$b$ & $69.8^{\mathrm{a}}$ & $67.8^{\mathrm{a}}$ & $67.6^{\mathrm{a}}$ & $53.4^{\mathrm{b}}$ & $35.1^{c}$ & 2.15 & $<0.001$ & $<0.001$ & $<0.001$ \\
\hline c & $2.69^{b}$ & $2.38^{\mathrm{b}}$ & $1.93^{b}$ & $2.71^{b}$ & $5.59^{\mathrm{a}}$ & 0.384 & $<0.001$ & $<0.001$ & $<0.001$ \\
\hline Lag & 6.2 & 3.2 & 0.0 & 0.0 & 4.7 & 1.49 & 0.052 & 0.217 & 0.008 \\
\hline$E D_{0.02}$ & $40.1^{\mathrm{b}}$ & $44.3^{\mathrm{ab}}$ & $46.4^{\mathrm{ab}}$ & $47.8^{\mathrm{a}}$ & $45.3^{\mathrm{ab}}$ & 1.57 & 0.049 & 0.018 & 0.038 \\
\hline \multicolumn{10}{|l|}{$\mathrm{CP}$} \\
\hline$a+b$ & NA & $67.0^{\mathrm{b}}$ & $68.2^{\mathrm{b}}$ & $75.8^{\mathrm{ab}}$ & $78.2^{\mathrm{a}}$ & 2.21 & 0.015 & 0.003 & 0.724 \\
\hline$a$ & NA & 23.5 & 16.4 & 22.0 & 19.9 & 2.42 & 0.158 & 0.656 & 0.339 \\
\hline$b$ & NA & 43.5 & 51.8 & 53.8 & 58.3 & 3.58 & 0.089 & 0.018 & 0.656 \\
\hline c & NA & $1.65^{c}$ & $4.65^{b c}$ & $8.67^{b}$ & $13.69^{a}$ & 1.00 & $<0.001$ & 0.007 & 0.456 \\
\hline Lag & NA & $0^{b}$ & $0^{b}$ & $4.9^{\mathrm{ab}}$ & $8.6^{\mathrm{a}}$ & 1.45 & 0.008 & 0.002 & 0.245 \\
\hline$E D_{0.05}$ & NA & 33.9 & 41.0 & 41.9 & 29.1 & 3.20 & 0.072 & 0.411 & 0.015 \\
\hline
\end{tabular}

$\overline{\mathrm{a}, \mathrm{b}, \mathrm{c}, \mathrm{d}}$ Means with different lowercased letters in the same row differ $(P<0.05)$ eSEM standard error of the means

${ }^{f} P$ values are shown for $P$ overall, $L$ linear effect, $Q$ quadratic effect

${ }^{9} a$ : soluble fraction (\%); $b$ : potentially degradable fraction (\%); $a+b$ : the maximum potential degradability; $c$ : the rate at which $b$ is degraded $(\% / h) ; \mathrm{ED}_{\mathrm{xxx}}$ : effective degradability (\%) at a ruminal passage rate of $0.05 / \mathrm{h}$ for $\mathrm{DM}$, and $0.02 / \mathrm{h}$ for aNDF, and $0.05 / \mathrm{h}$ for CP; NA: value not be estimated

protein synthesis. The linearly-increased ammonia-N accumulation with increasing PPC at all maturities is a reflection of the increasing protein concentration in the mixture. Whether microbial protein synthesis (ammonia-N utilization) was affected by the inclusion of PPC was not determined in this study. Nevertheless, Jin et al. [3] found that incorporation of PPC at full flower/early seedpod stage into cool-season grasses up to $44.8 \%$ linearly increased microbial protein synthesis. One of the most common effects of dietary CT on protein degradation in the rumen is a decrease in ruminal ammonia concentrations [35]. Decreased ammonia production by PPC CT was also reported in our previous studies [10, $11,13]$. In this study, regardless of plant maturity, PPC contained higher amounts of protein and CT and produced more ammonia-N than cool-season grasses. The linearly-increased protein degradability of the PPCgrass mixtures as the protein concentration increased was consistent with the increase in ammonia- $\mathrm{N}$ production in the in vitro experiment. Dal Pizzol et al. [7] also reported that incorporation of legume forage (sainfoin) containing CT into grass linearly increased ruminal ammonia- $\mathrm{N}$ production. The decrease of protein disappearance of PPC: grasses mixture at the ratio of 0:100 on 2,12 , and $24 \mathrm{~h}$ of the incubation was due to the increased microbial colonization that surpassed the protein disappearance from the feed particles during this period of incubation. This phenomenon is commonly observed with poor quality roughages of low $\mathrm{N}$ content $[36,37]$. Because DM and CP disappearances were not corrected by microbial $\mathrm{N}$ and microbial mass, these values were underestimations of the corresponding true $\mathrm{DM}$ and $\mathrm{CP}$ disappearances in this study. In addition, Figs. 3 and 4 showed that disappearances of DM, aNDF and CP slightly increased for mixture with high proportion of grasses (100\% and 75\%) between 72 and $96 \mathrm{~h}$ of the ruminal incubation. Therefore, there might be a chance that the ruminal degradation of these substrates did not reached a plateau at the 96-h incubation, which might slightly affect the kinetic parameters estimated 


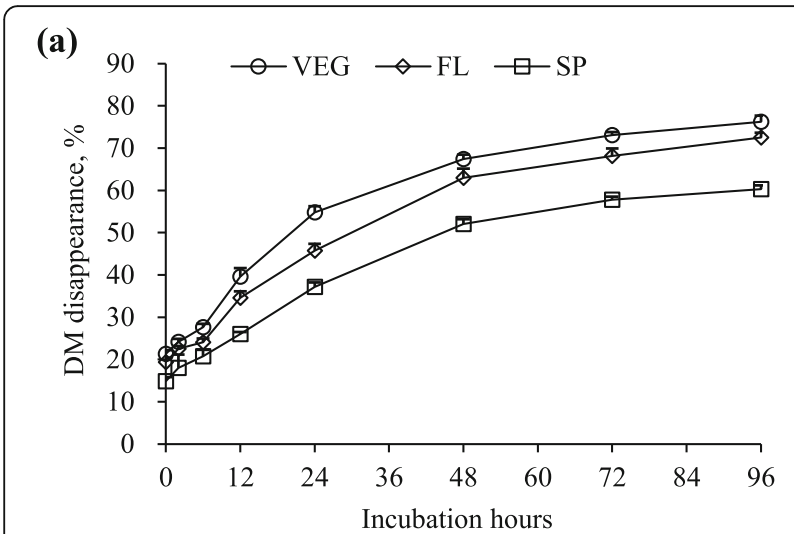

(b)

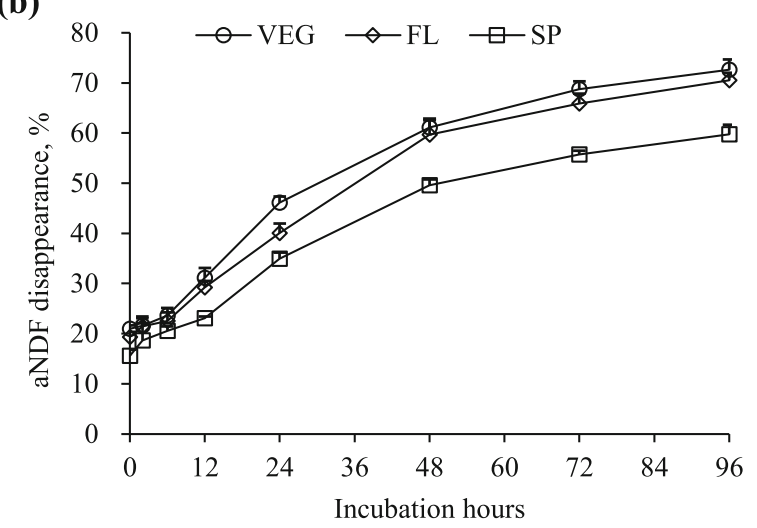

(c)

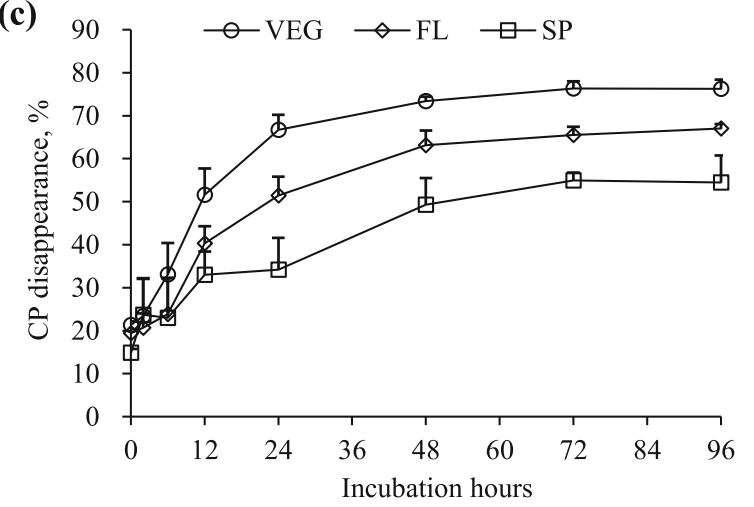

Fig. 5 Disappearances of dry matter $(D M$, a) neutral detergent fibre (aNDF, b) and crude protein (CP, c) during 96-h incubation of mixtures of purple prairie clover (PPC; Dalea purpurea Vent.) and cool-season grasses in the ratio of 50:50. Both PPC and grass were harvested when PPC reached the vegetative (VEG), full flower (FL) and seedpod (SP) stages

from them. Ruminal incubation longer than 96-h and correction for microbial $\mathrm{N}$ contamination in the incubation residue are needed to accurately estimate the ruminal degradation parameters for such feed types.

The result that increasing PPC proportion in the PPCgrass mixture increased acetate: propionate ratio by increasing acetate and decreasing propionate was consistent with Jin et al. [3]. The variations of these major VFAs
Table $\mathbf{5}$ In situ ruminal degradation characteristics of dry matter (DM), neutral detergent fiber (aNDF), and crude protein (CP) disappearance of a 50:50 mixture of purple prairie clover (PPC; Dalea purpurea Vent.) and cool-season grasses. Both PPC and grass were harvested when PPC reached the vegetative (VEG), full flower (FL) and seedpod (SP) stages

\begin{tabular}{|c|c|c|c|c|c|}
\hline Items $^{d}$ & VEG & $\mathrm{FL}$ & $\mathrm{SP}$ & $\mathrm{SEM}^{\mathrm{C}}$ & $P$-value \\
\hline \multicolumn{6}{|l|}{ DM } \\
\hline$a+b$ & $78.3^{\mathrm{a}}$ & $77.6^{\mathrm{a}}$ & $66.3^{b}$ & 0.80 & $<0.001$ \\
\hline$a$ & $19.8^{\mathrm{a}}$ & $18.3^{\mathrm{a}}$ & $14.4^{b}$ & 0.74 & 0.002 \\
\hline$b$ & $58.5^{\mathrm{a}}$ & $59.3^{\mathrm{a}}$ & $51.9^{b}$ & 0.67 & $<0.001$ \\
\hline$c$ & $3.50^{\mathrm{a}}$ & $2.65^{b}$ & $2.46^{\mathrm{b}}$ & 0.081 & $<0.001$ \\
\hline Lag & 0 & 0 & 0 & - & - \\
\hline$E D_{0.05}$ & $43.9^{\mathrm{a}}$ & $38.8^{b}$ & $31.5^{c}$ & 0.45 & $<0.001$ \\
\hline \multicolumn{6}{|l|}{ aNDF } \\
\hline$a+b$ & $77.7^{\mathrm{a}}$ & $80.8^{a}$ & $60.0^{b}$ & 2.20 & 0.001 \\
\hline$a$ & $15.3^{\mathrm{a}}$ & $13.2^{\mathrm{a}}$ & $7.5^{b}$ & 0.75 & $<0.001$ \\
\hline$b$ & $62.3^{\mathrm{a}}$ & $67.6^{\mathrm{a}}$ & $52.6^{\mathrm{b}}$ & 2.43 & 0.021 \\
\hline c & 2.64 & 1.93 & 2.71 & 0.274 & 0.156 \\
\hline Lag & $1.9^{\mathrm{ab}}$ & $0.0^{b}$ & $5.9^{\mathrm{a}}$ & 1.20 & 0.034 \\
\hline$E D_{0.02}$ & $47.0^{\mathrm{a}}$ & $46.4^{a}$ & $30.3^{b}$ & 1.59 & 0.002 \\
\hline \multicolumn{6}{|l|}{$C P$} \\
\hline$a+b$ & $76.9^{\mathrm{a}}$ & $68.2^{\mathrm{ab}}$ & $59.7^{b}$ & 3.70 & 0.058 \\
\hline$a$ & 18.0 & 16.4 & 18.4 & 2.24 & 0.788 \\
\hline$b$ & $58.9^{\mathrm{a}}$ & $51.8^{\mathrm{ab}}$ & $41.3^{b}$ & 3.34 & 0.027 \\
\hline c & 6.69 & 4.58 & 3.60 & 0.889 & 0.135 \\
\hline Lag & 0 & 0 & 2.0 & 1.14 & 0.444 \\
\hline$E D_{0.05}$ & $51.3^{\mathrm{a}}$ & $41.0^{\mathrm{b}}$ & $32.0^{\mathrm{b}}$ & 3.29 & 0.011 \\
\hline
\end{tabular}

a,b Means with different lowercased letters differ $(P<0.05)$ 'SEM standard error of the mean

${ }^{\mathrm{d}} a$ : soluble fraction (\%); $b$ : potentially degradable fraction (\%); $a+b$ : the maximum potential degradability; c: the rate at which $b$ is degraded $(\% / h)$; $E D_{\text {xxx }}$ : effective degradability (\%) at a ruminal passage rate of $0.05 / \mathrm{h}$ for $\mathrm{DM}$, and $0.02 / \mathrm{h}$ for NDF, and $0.05 / \mathrm{h}$ for $\mathrm{CP}$

caused by the inclusion of PPC may be specific to the two types of the forages used in this study, as Burke et al. [38] compared the VFA profiles of eight temperate grasses and six temperate legumes and found no difference in VFA profiles after ruminal fermentation of these various species. It is also likely that the antimicrobial activity of CT in PPC contributed partially to the variation in VFA profiles. The effects of CT in PPC on increasing acetate: propionate ratio during ruminal fermentation has been demonstrated by both in vitro and in vivo studies $[3,11,13]$. The negative effect of PPC CT on propionate production might reflect the ability of these phenolics to inhibit specific members of the microbiota, such as Prevotella bryantii [39] or Ruminobacter amylophilus [40], because both of these produce propionate in the rumen [41].

It is generally regarded that the nutritional role of $\mathrm{CT}$ in ruminant nutrition depends on their dietary concentrations 
and chemical composition [11, 42, 43]. Purple prairie clover was the only forage that contained CT in this study and the CT concentration increased as increasing PPC was added to the grass mixture. Both in vitro and in situ studies showed PPC CT at concentrations up to $82 \mathrm{~g} / \mathrm{kg}$ DM had minimal impact on ruminal feed digestion $[11,12]$. In contrast, $\mathrm{CT}$ in other temperate forages have been shown to have negative effects on nutrient digestion at CT concentrations $>50 \mathrm{~g} / \mathrm{kg}$ DM [35]. Huang et al. [32] found that PPC $\mathrm{CT}$ were predominantly composed of procyanidins with less $-\mathrm{OH}$ than prodelphinidins type and as a result lower biological activity. The same authors also found that reactivity of PPC CT with proteins decreased with advancing PPC maturity as a result of increased mean degree of polymerization. Therefore, the reduction in ruminal digestion with advancing maturity in PPC is likely a result of increased ADF deposition rather than as a result of the presence of CT.

\section{Conclusion}

Purple prairie clover contained higher protein than coolseason grasses throughout the growing season and therefore the incorporation of PPC into cool-season grasses would increase the protein content of forage in rehabilitated native pasture. However, the improvement in nutritive value of the forage by the incorporation of PPC into native pasture depends on the PPC growth stage, with greatest benefit being obtained at the vegetative stage followed by full flower and seedpod stages. Considering the faster decline of nutrient digestion of PPC over the growth season than cool-season grasses and balanced by $\mathrm{N}$ content of the two types of forages, it seems that about $50 \%$ of PPC in the PPC-grass mixed forage would provide most benefit for the purpose of extending the grazing season. These results need to be confirmed with field trials to better understand competition ability between PPC and cool season-grasses.

\section{Abbreviations \\ A: Acetate; ADF: Acid detergent fibre; aNDF: neutral detergent fibre; CP: Crude protein; CT: Condensed tannins; DM: Dry matter; ECT: Extractable condensed tannins; ED: Effective degradability; FL: Full flower; GP: Gas production; IVDMD: In vitro dry matter disappearance; LRDC: Lethbridge Research and Development Centre; N: Nitrogen; OM: Organic matter; P: Propionate; PPC: Purple prairie clover; SP: Seedpod; VEG: Vegetative; VFA: Volatile fatty acid}

\section{Acknowledgements}

The authors would like to thank Dr. Long Jin and the feedlot staffs in LRDC for their technical assistances.

\section{Authors' contributions}

YW, TAM and KP conceived and designed the experiments. KP, ZX and GLG performed the experiments. Al and MS collected the forage samples. KP and YW analyzed the data. KP, YW and AVC wrote the paper. All authors read and approved the final manuscript.

\section{Funding}

This study was funded from AAFC/Canadian Beef Cattle Industry Science Cluster, and Alberta Livestock and Meat Agency. This is Lethbridge Research and Development Centre contribution number 38717038.

\section{Availability of data and materials}

The datasets supporting the conclusions of this article are included within the article.

\section{Ethics approval and consent to participate}

All cows used in this study were cared for according to guidelines set by the Canadian Council on Animal Care (CCAC, 2009) and the protocol was approved by the LRDC Animal Care Committee (ACC-2016-1524).

\section{Consent for publication}

Not applicable.

\section{Competing interests}

The authors declare that they have no competing interests.

\section{Author details}

${ }^{1}$ Key Laboratory of Animal Nutrition and Feed Science (South China) of Ministry of Agriculture, Guangdong Key Laboratory of Animal Breeding and Nutrition, Institute of Animal Science, Guangdong Academy of Agricultural Science, Guangzhou 510640, People's Republic of China. ${ }^{2}$ Agriculture and Agri-Food Canada, Lethbridge Research and Development Centre, Lethbridge, AB T1J 4B1, Canada. ${ }^{3}$ School of Life and Environmental Sciences, The University of Sydney, Sydney, NSW 2006, Australia. ${ }^{4}$ Agriculture and Agri-Food Canada, Swift Current Research and Development Centre, Swift Current, SK S9H 3X2, Canada.

Received: 8 August 2019 Accepted: 22 December 2019

Published online: 14 February 2020

\section{References}

1. Jefferson PG, McCaughey WP, May K, Woosaree J, McFarlane L. Forage quality of seeded native grasses in the fall season on the Canadian prairie provinces. Can J Plant Sci. 2004;84:503-9.

2. Schellenberg MP, Banerjee MR. The potential of legume-shrub mixtures for optimum forage production in southwestern Saskatchewan: a greenhouse study. Can J Plant Sci. 2002;82:357-63.

3. Jin L, Wang $Y$, Iwaasa AD, Xu Z, Schellenberg MP, Zhang YG, et al. Short communication: effect of condensed tannin on in vitro ruminal fermentation of purple prairie clover (Dalea purpurea Vent.)-cool-season grass mixture. Can J Anim Sci. 2013;93:155-8.

4. Luscher A, Mueller-Harvey I, Soussana JF, Rees RM, Peyraud JL. Potential of legume-based grassland-livestock systems in Europe: a review. Grass Forage Sci. 2014;69:206-28.

5. Elgersma A, Soegaard K. Effects of species diversity on seasonal variation in herbage yield and nutritive value of seven binary grass-legume mixtures and pure grass under cutting. Eur J Agron. 2016;78:73-83.

6. Pembleton KG, Hills JL, Freeman MJ, Mclaren DK, French M, Rawnsley RP. More milk from forage: milk production, blood metabolites, and forage intake of dairy cows grazing pasture mixtures and spatially adjacent monocultures. J Dairy Sci. 2016;99:3512-28.

7. Dal Pizzol JG, Ribeiro-Filho HMN, Quereuil A, Le Morvan A, Niderkorn V. Complementarities between grasses and forage legumes from temperate and subtropical areas on, in vitro, rumen fermentation characteristics. Anim Feed Sci Technol. 2017;228:178-85.

8. Sheaffer DLWCC, Ehlke NJ. Palatability and nutritive value of native legumes. Native Plants J. 2009;10:225-31.

9. Mischkolz JM, Schellenberg MP, Lamb EG. Early productivity and crude protein content of establishing forage swards composed of combinations of native grass and legume species in mixed-grassland ecoregions. Can J Plant Sci. 2013;93:445-54.

10. Huang Q, Peng K, Iwaasa A, Schellenberg M, McAllister T, Wang Y. Effects of condensed tannins in purple prairie and white prairie clover on ruminal fermentation and methane production in vitro. J Anim Sci. 2018; 96(supplement 3):422.

11. Jin $L$, Wang $Y$, Iwaasa $A D, X u Z$, Schellenberg MP, Zhang $Y G$, et al. Effect of condensed tannins on ruminal degradability of purple prairie clover (Dalea 
purpurea Vent.) harvested at two growth stages. Anim Feed Sci Technol. 2012;176:17-25.

12. Huang QQ, Jin L, Xu Z, Acharya S, McAllister TA, Hu TM, et al. Effects of conservation method on condensed tannin content, ruminal degradation, and in vitro intestinal digestion of purple prairie clover (Dalea purpurea vent.). Can J Anim Sci. 2016:96:524-31.

13. Peng K, Shirley DC, Xu Z, Huang Q, McAllister TA, Chaves AV, et al. Effect of purple prairie clover (Dalea purpurea vent.) hay and its condensed tannins on growth performance, wool growth, nutrient digestibility, blood metabolites and ruminal fermentation in lambs fed total mixed rations. Anim Feed Sci Technol. 2016;222:100-10.

14. NRC. Nutrient requirements of small ruminants. 7th ed. Washington, DC: National Academy of Science; 2007.

15. Canadian Council on Animal Care (CCAC). Guidelines on the care and use of farm animals in research, teaching and testing. Ottawa: CCAC; 2009.

16. Wang Y, McAllister TA, Yanke LJ, Xu ZJ, Cheeke PR, Cheng KJ. In vitro effects of steroidal saponins from Yucca schidigera extract on rumen microbial protein synthesis and ruminal fermentation. J Sci Food Agric. 2000;80:2114-22.

17. Mauricio RM, Mould FL, Dhanoa MS, Owen E, Channa KS, Theodorou MK. A semi-automated in vitro gas production technique for ruminant feedstuff evaluation. Anim Feed Sci Technol. 1999;79:321-30.

18. Zahiroddini H, Baah J, Absalom W, McAllister T. Effect of an inoculant and hydrolytic enzymes on fermentation and nutritive value of whole crop barley silage. Anim Feed Sci Technol. 2004;117:317-30.

19. AOAC, editor. Official methods of analysis of the association of official agricultural chemists. 16th ed. Gaithersburg: AOAC International; 1999. 5th rev

20. McGinn SM, Beauchemin KA, Coates T, Colombatto D. Methane emissions from beef cattle: effects of monensin, sunflower oil, enzymes, yeast, and fumaric acid. J Anim Sci. 2004;82:3346-56.

21. Terrill TH, Rowan AM, Douglas GB, Barry TN. Determination of extractable and bound condensed tannin concentrations in forage plants, protein concentrate meals and cereal grains. J Sci Food Agric. 1992;58:321-9.

22. Wang Y, Xu Z, Bach SB, McAllister TA. Sensitivity of Escherichia coli O157:HZ to seaweed (Ascophyllum nodosum) phlorotannins and terrestrial tannins. Asian-Austral J Anim Sci. 2009;22:238-45.

23. McDonald I. A revised model for the estimation of protein degradability in the rumen. J Agric Sci. 1981;96:251-2.

24. Orskov $E, M c D o n a l d ~ I$. The estimation of protein degradability in the rumen from incubation measurements weighted according to rate of passage. J Agric Sci. 1979;92:499-503.

25. Ohlsson C, Houmoller LP, Weisbjerg MR, Lund P, Hvelplund T. Effective rumen degradation of dry matter, crude protein and neutral detergent fiber in forage determined by near infrared reflectance spectroscopy. J Anim Physiol Anim Nutr. 2007;91:498-507.

26. SAS. SAS Online Doc ${ }^{\circledR}$ 9.1.3. Cary: SAS Institute Inc; 2012.

27. Buxton DR. Quality-related characteristics of forages as influenced by plant environment and agronomic factors. Anim Feed Sci Technol. 1996;59:37-49.

28. Posler GL, Lenssen AW, Fine GL. Forage yield, quality, compatibility, and persistence of warm-season grass—legume mixtures. Agron J. 1993;85:554-60.

29. Stubbendieck J, Conard EC. Common legumes of the Great Plains: an illustrated guide. Lincoln: University of Nebraska Press; 1989. p. 330.

30. Wang Y, Berg BP, Barbieri LR, Veira DM, McAllister TA. Comparison of alfalfa and mixed alfalfa-sainfoin pastures for grazing cattle: effects on incidence of bloat, ruminal fermentation, and feed intake. Can J Anim Sci. 2006;86:383-92.

31. Li Y, Iwaasa AD, Wang Y, Jin L, Han G, Zhao M. Condensed tannins concentration of selected prairie legume forages as affected by phenological stages during two consecutive growth seasons in western Canada. Can J Plant Sci. 2014;94:817-26.

32. Huang $Q, H u T, X u Z$, Jin L, McAllister $T A$, Acharya $S$, et al. Structural composition and protein precipitation capacity of condensed tannins from purple prairie clover (Dalea purpurea Vent.). J Anim Sci. 2017;95(supplement 4):141.

33. Van Soest PJ. Nutritional ecology of the ruminant. 2nd ed. Ithaca: Cornell University Press; 1994. p. 476.

34. Sturludottir E, Brophy C, Bélanger G, Gustavsson AM, Jørgensen M, Lunnan T, et al. Benefits of mixing grasses and legumes for herbage yield and nutritive value in northern Europe and Canada. Grass Forage Sci. 2014;69:229-40.

35. Waghorn GC. Beneficial and detrimental effects of dietary condensed tannins for sustainable sheep and goat production - progress and challenges. Anim Feed Sci Technol. 2008;147:116-39.

36. Varvikko T, Lindberg JE. Estimation of microbial nitrogen in nylon-bag residues by feed ${ }^{15} \mathrm{~N}$ dilution. Brit J Nutr. 1985;54:473-81.
37. Krawielitzki K, Schmidt T, Voigt J, Kowalczyk J, Gabel M. Dynamics of microbial contamination of protein during ruminal in situ incubation of feedstuffs. J Anim Feed Sci. 2006;15:2867-9.

38. Burke JL, Waghorn GC, Brookes IM, Chaves AV, Attwood GT. In vitro production of volatile fatty acids from forages. Proc N Z Soc Anim Prod. 2006;66:50-4.

39. Min BR, Attwood GT, McNabb WC, Molan AL, Barry TN. The effect of condensed tannins from Lotus corniculatus on the proteolytic activities and growth of rumen bacteria. Anim Feed Sci Technol. 2005;121:45-58.

40. Jones GA, McAllister TA, Muir AD, Cheng KJ. Effects of sainfoin (Onobrychis viciifolia Scop.) condensed tannins on growth and proteolysis by four strains of ruminal bacteria. Appl Environ Microbiol. 1994;60:1374-8.

41. Narvaez N, Wang Y, Xu Z, Alexander T, Garden S, McAllister T. Effects of hop varieties on ruminal fermentation and bacterial community in an artificial rumen (rusitec). J Sci Food Agric. 2013:93:45-52.

42. Soltan YA, Morsy AS, Sallam S. Comparative in vitro evaluation of forage legumes (prosopis, acacia, atriplex, and leucaena) on ruminal fermentation and methanogenesis. J Anim Feed Sci. 2012;21:759-72.

43. Hatew B, Stringano E, Mueller-Harvey I, Hendriks WH, Carbonero CH, Smith LMJ, et al. Impact of variation in structure of condensed tannins from sainfoin (Onobrychis viciifolia) on in vitro ruminal methane production and fermentation characteristics. J Anim Physiol Anim Nutr. 2016;100:348-60.

\section{Ready to submit your research? Choose BMC and benefit from:}

- fast, convenient online submission

- thorough peer review by experienced researchers in your field

- rapid publication on acceptance

- support for research data, including large and complex data types

- gold Open Access which fosters wider collaboration and increased citations

- maximum visibility for your research: over $100 \mathrm{M}$ website views per year

At BMC, research is always in progress.

Learn more biomedcentral.com/submissions 